\title{
PENINGKATAN PELAYANAN MUATAN KENDARAAN PADA KAPAL KM. MUTIARA TIMUR 1
}

\section{( Studi Pada PT. Atosim Lampung Pelayaran Cabang Semarang )}

\author{
Tini Utami ${ }^{{ }^{*}}$, Aditya Mutiara Dewi ${ }^{2}$ \\ ${ }^{1}$ Program Studi Ketatalaksanaan Pelayaran Niaga dan Kepelabuhanan, Politeknik Bumi Akpelni \\ Jln. Pawiyatan Luhur II/17, Bendan Dhuwur Semarang \\ ${ }^{2}$ Program Studi Transportasi Laut, Politeknik Bumi Akpelni \\ J1. Pawiyatan Luhur II/17, Bendan Dhuwur Semarang \\ *Email:tini@akpelni.ac.id
}

\begin{abstract}
Abstrak
Penelitian ini bertujuan untuk mengetahui tentang Strategi yang diterapkan oleh PT Atosim Lampung Cabang Semarang dalam Peningkatan Pelayanan Jasa Penumpang Dan Barang pada Kapal Ro-Ro, serta mengetahui apa faktor pendukung dan penghambat pelaksanaannya. Dalam penelitian ini peneliti menggunakan jenis penelitian diskriptif dengan pendekatan kualitatif dan menggunakan metode analisis Miles Huberman. Dari hasil penelitian telah diperoleh bahwa: Strategi peningkatan pelayanan jasa penumpang dan barang Kapal Ro-Ro dapat dikategorikan berhasil dalam mengatasi masalah - masalah yang ada, seperti halnya pelayanan jasa, jaminan kerugian, sarana prasarana, sistem E-Ticketing, kenyamanan dan keamanan. Selain itu, hasil penelitian ini juga berdasarkan pada penggunaan penerapan Lima Elemen Service Quality (ServQual) seperti Reliability, Assurance, Tangible, Empathy, dan Responsiveness (RATER) oleh PT Atosim Lampung Pelayaran Cabang Semarang.
\end{abstract}

Kata kunci : kapal Roro, peningkatan, dan pelayanan

\section{PENDAHULUAN}

Indonesia merupakan negara kepulauan atau sebagai negara maritim, sehingga peranan pelayaran sangat penting bagi suatu kehidupan sosial, ekonomi, pemerintahan, pertahanan / keamanan, dan sebagainya. Selain itu, Bidang kegiatan pelayaran sangat luas yang meliputi angkutan penumpang, angkutan barang, penjagaan pantai, hidrografi, serta masih banyak lagi jenis kegiatan pelayaran lainnya.

Sebagai suatu negara kepulauan yang mempunyai lebih dari 3.700 pulau dan wilayah pantai sepanjang $80.000 \mathrm{~km}$ atau dua kali keliling dunia melalui katulistiwa, kegiatan angkutan pelayaran sangat diperlukan untuk dapat menghubungkan antar satu pulau dengan pulau yang lain juga dengan satu pelabuhan dengan pelabuhan lain.

Berdasarkan Undang-udang Nomor 23 Tahun 2014 Tentang Pemerintah Daerah, Urusan pemerintahan wajib yang diselenggarakan oleh Pemerintah Daerah terbagi menjadi 2 ( dua) yaitu Urusan yang berkaitan dengan pelayanan dasar dan
Urusan Pemerintahan yang tidak berkaitan dengan pelayanan dasar.

Salah satu urusan Pemerintahan yang tidak berkaitan dengan pelayanan dasar adalah perhubungan, sehingga sektor transportasi dikenal sebagai salah satu mata rantai jaringan distribusi barang dan penumpang telah berkembang demikian dinamis serta berperan didalam menunjang pembangunan dibidang politik, ekonomi, sosial budaya maupun pertahanan keamanan. Pertumbuhan sektor ini akan tercermin dalam perkembangan ekonomi secara langsung sehingga transportasi dapat dilihat dari kemampuannya untuk menunjang serta mendorong peningkatan ekonomi nasional, regional dan lokal, dalam stabilitas politik termasuk dalam mewujudkan nilai-nilai sosial dan budaya yang diindikasikan melalui berbagai indikator transportasi antara lain : kapasitas, kualitas pelayanan, aksesibilitas keterjangkauan, beban politik dan utilisasi.

Kebutuhan terhadap jasa transportasi laut sangat penting dalam kehidupan masyarakat. Hal tersebut dapat dirasakan manfaatnya disemua sektor perdagangan 
karena transportasi laut memiliki kelebihan dalam pengangkutan jika dibandingkan dengan transportasi lainnya. Selain itu, transportasi ini juga dapat memuat barang dan / atau penumpang yang lebih besar dan tarifnya juga lebih murah. Dalam masalah angkutan penumpang laut, diarahkan untuk menjamin tersedianya jasa angkutan dalam kualitas serta kuantitas yang dapat memadai sehingga dapat membantu dalam pemerataan dari hasil pembangunan, memperkokoh persatuan dan kesatuan bangsa untuk meningkatkan ketahanan Nasional untuk mewujudkan Wawasan Nusantara.

Di Indonesia saat ini, kapal Roro merupakan salah satu alat transportasi yang cukup diminati oleh masyarakat, khususnya untuk daerah atau propinsi yang belum terjangkau oleh angkutan transportasi lain, walaupun kenyataan yang ada adalah kapal yang mengangkut penumpang dan barang belum dapat bersaing dari sisi jasa transportasi jika dibandingkan dengan transportasi lainnya seperti pesawat udara, bus dan kereta api. Transportasi laut untuk kapal penumpang secara terus-menerus berusaha melakukan perbaikan yang dianggap kurang memadai secara bertahap dilakukan perbaikan-perbaikan, penambahan fasilitas- fasilitas yang memadai dalam pelayanan penumpang dan barang yang sesuai agar dapat bersaing dengan transportasi lain dan menarik minat masyarakat untuk dapat menjadi satu pilihan transportasi yang murah dan berkualitas. Perusahaan Pelayaran PT. Atosim Lampung Pelayaran (PT. ALP) yang salah satu operasional pelayanan jasanya adalah juga mengoperasionalkan beberapa kapal Ro-Ro ke wilayah Indonesia, senantiasa melakukan perbaikanperbaikan secara terus menerus dengan kualitas pelayanan sesuai dengan keinginan konsumen atau masyarakat yang lebih baik dan dapat mengatasi persaingan dengan jasa transportasi lain. Oleh karena itu, perusahaan dituntut selalu sigap dan mampu mengantisipasi berbagai perubahan yang terjadi dimasa sekarang maupun dimasa yang akan datang. Melihat hal tersebut, maka peningkatan kinerja dan produktivitas perusahaan dilakukan dengan berbagai cara untuk menjaga kelangsungan hidup perusahaan tercapai.

Kualitas pelayanan memegang peranan yang sangat penting dalam menentukan kepuasan konsumen / pengguna jasa (Gaspersz, 2008). Untuk menunjang kualiatas layanan yang baik selain harus ditunjang dengan teknik dan prosedur yang benar sehingga fasilitasfasilitas yang terdapat pada perusahaan dapat berfungsi dengan baik, juga indikator kinerja keselamatan perlu dikembangkan karena dapat dijadikan perbandingan dengan moda lain (Mudana, 2014). Pelayanan transpotasi laut tidak dapat dihindarkan dari transformasi digitalisasi jika ingin terus berkembang. Untuk itu, dengan adanya penerapan sistem $E$ ticketing kapal penumpang di pelabuhan, dapat memberikan kemajuan jasa pelayanan kapal penumpang angkutan laut, peningkatan kenyamanan penumpang kapal seperti dapat membawa barangnya sendiri pada saat menaiki kapal tersebut.

Penerapan E-ticketing dapat membantu meningkatkan kenyamanan penumpang dan barang, mempermudah melakukan pengawasan pengendalian dan pengaturan pelayanan penumpang barang dan kendaraan di pelabuhan, serta mempermudah memperoleh data penumpang dan barang di kapal dalam rangka mendukung keselamatan berlayar. Disamping itu, hal ini juga memberikan kemudahan mengenai tata cara pelayanan dan pemeriksaan penumpang, barang dan kendaraan sebelum naik ke kapal (Check in) kepada petugas pelabuhan , Pelindo, petugas kapal, dan petugas pengawasan (Otoritas Pelabuhan / Syahbandar/ KPLP). PT. Atosim Lampung Pelayaran sebagai salah satu perusahaan jasa angkutan laut yang memiliki kantor cabang sebanyak 10 unit yang berada di seluruh Indonesia, salah satu Cabangnya yang ada di Semarang menjalankan 2 (dua) pengoperasian kapal di Pelabuhan Tanjung Emas Semarang, 
dengan memberlakukan sistem E-ticketing. Namun hal tersebut tidak langsung berjalan efektif karena ada permasalahan mengenai penanganan pelayanan E-ticketing tersebut.

Sehubungan dengan judul diatas, dan agar penelitian ini tidak bias, maka permasalahan penelitian dirumuskan sebagai berikut :

1. Bagaimanakah pelaksanaan pelayanan terhadap jaminan keamanan kerusakan kendaraan yang membawa muatan.

2. Bagaimanakah kelengkapan sarana dan prasarana dalam sistem penangan pelayanan E-ticketing

3. Bagaimanakah pemahaman konsep antar pihak yang terlibat dalam sistem penanganan pelayanan E-ticketing.

Dengan adanya permasalahan tersebut, PT. Atosim Lampung Pelayaran Cabang Semarang dituntut segera mencari jalan keluar yang tepat untuk mengantisipasi dari permasalahan yang muncul. Disisi lain, bagi penumpang dan barang khususnya kapal RoRo tidak beralih ke transportasi lainnya. Saat ini PT. ALP Cabang Semarang melakukan peningkatan pelayanan untuk mengatasi beberapa permasalah yang ada, seperti pada kapal KM. Mutiara Timur 1 rute kapal laut Semarang (Tanjung Emas) - Lampung (Panjang) mempunyai prospek yang sangat bagus, antara lain menekan biaya bagi penumpang maupun kendaraan, memelihara perawatan jalan raya, penghematan perawatan kendaraan truck dan/atau truk yang melalui jalan darat dibanding truk yang menggunakan kapal laut ke Lampung- Semarang, juga faktor keamanan barang, dan perusahaan logistik. Prospek Short Sea Shipping akan menjadi pilihan utama sebab dari sudut perhitungan biaya dan tenaga akan lebih hemat. Termasuk untuk tarif penumpang, pihak PT. ALP hanya menaikkan $20 \%$ saja dari angkutan kapal ferry/ kapal penyeberangan Merak - Bakauheuni, padahal dari segi jarak tempuh sangat jauh berbeda. Sebagai perusahaan yang bergerak dalam bidang jasa transportasi, PT. ALP harus dapat memenuhi keinginan konsumen untuk menciptakan dan mengembangkan kualitas pelayanan.

Tujuan yang ingin dicapai pada penelitian ini adalah untuk mendapatkan pemahaman lebih mendalam berkenaan dengan pelaksanaan pelayanan kepada masyarakat yang prima dari PT. ALP Cabang Semarang untuk penanganan jasa transportasi laut pengangkutan Penumpang dan Barang.

\section{LANDASAN TEORI}

\section{Strategi Peningkatan Pelayanan}

Kotler (20003 : 191) mendefinisikan bahwa strategi adalah perekat yang bertujuan untuk membangun dan memberikan proposisi nilai yang konsisten dan membangun citra yang berbeda kepada pasar sasaran.

Upaya yang dilakukan oleh PT. ALP Cabang Semarang agar tujuan dapat terlaksana dengan baik tentunya dibentuk langkah-langkah atau tindakan dalam pencapaian tujuan perusahaan. Untuk dapat mencapai tujuan pelayanan yang baik tentunya tidak mudah, karena jika ada seorang pelanggan yang kecewa dengan pelayanan yang diberikan tentunya akan berakibat bisa menjadi besar yaitu membuat stigma yang negatif terhadap pelayanan yang telah diberikan. Dengan demikian, perusahaan harus memberikan kualitas pelayanan yang dapat membuat perusahaan tersebut berkembang. Bentuk upaya agar tujuan terlaksana dengan baik yang dilakukan Perusahaan dimana Zeithaml, Bitner dan Dwayne (2009,p.104) mengungkapkan ada lima faktor paling dominan atau penentu kualitas jasa melalui Elemen Service Quality (ServQual) yang merupakan salah satu konsep layanan perusahaan yang dapat diandalkan untuk bertahan di tengah persaingan yang semakin ketat. ServQual memiliki lima elemen utama yaitu :

\section{1) Reliability (Keandalan)}

yaitu kemampuan untuk memberikan pelayanan yang sesuai dengan janji yang ditawarkan, seperti informasi yang akurat, penanganan konsumen, kemudahan 
pemesanan tiket, penyediaan pelayanan sesuai perjanjian, pelayanan yang tepat petama kali, penanganan masalah konsumen, dan penyediaan pelayanan tepat waktu.

2). Assurance (Kepastian),

yaitu meliputi kemampuan karyawan atas pengetahuan terhadap produk secara tepat, pelayanan yang adil pada konsumen, kualitas keramah-tamahan, perhatian dan kesopanan dalam memberikan pelayanan, ketrampilan dalam memberikan informasi, kemampuan dalam memberikan keamanan didalam memanfaatkan jasa yang ditawarkan, dan menanamkan kepercayaan pelanggan terhadap perusahaan, yang terdiri dari :

a. Kompetensi (Competence), meliputi ketrampilan dan pengetahuan yang dimilki oleh para karyawan untuk melakukan pelayanan;

b. Kesopanan (Courtesy), meliputi keramahan, perhatian dan sikap para karyawan;

c. Kredibilitas (credibility), meliputi halhal yang berhubungan dengan kepercayaan kepada perusahaan, seperti reputasi, dan prestasi.

3). Tangible (berwujud), yaitu penampilan fisik, seperti gudang dan ruangan front office, kebersihan, kerapian, dan kenyamanan ruangan, kelengkapan peralatan komuniksi, dan jumlah dan penampilan karyawan.

4). Empathy (empati),

yaitu perhatian secara individual yang diberikan oleh perusahaan kepada pelanggan, seperti kemudahan untuk menghubungi perusahaan, kemampuan karyawan untuk berkomunikasi dengan pelanggan, dan usaha perusahaan untuk memahami keinginan dan kebutuhan pelanggannya. Dimensi ini merupakan penggabungan dari dimensi :

a. Akses (access), meliputi kemudahan untuk memanfaatkan jasa yang ditawarkan perusahaan;

b. Komunikasi (communication), meliputi kemampuan melakukan komunikasi untuk menyampaikan informasi kepada pelanggan atau memperoleh masukan dari pelanggan.

c. Pemahaman pada pelanggan (understanding the customer), meliputi usaha perusahaan untuk mengetahui dan memahami kebutuhan dan keinginan pelanggan.

5). Responsiveness (daya tanggap),

yaitu respon atau kesigapan karyawan dalam membantu pelanggan dan memberi pelayanan yang cepat dan tanggap, yang meliputi kesigapan karyawan dalam melayani konsumen, kerja tim yang baik, kecepatan karyawan dalam menangani transaksi dan penanganan keluhan konsumen, siap sedia menanggapi pertanyaan konsumen, penyampaian informasi saat pelayanan, pemberian layanan ekstra, dan kemauan untuk membantu konsumen.

\section{Jasa}

Menurut Zeithaml dan Bitner dalam Ratih Hurriyati (2005;28) Jasa merupakan seluruh aktivitas ekonomi dengan output selain produk dalam pengertian fisik, dikomsumsi dan diproduksi pada saat bersamaan, memberikan nilai tambah dan secara prinsip tidak berwujud (intangible) bagi pembeli pertamanya.

\section{Karakteristik Jasa}

Karakteristik jasa merupakan sifat dari jasa yang ditawarkan oleh sutu pihak kepada pihak lain yang berfungsi untuk membedakan produk barang. Menurut Kotler dan Armstrong (2012:223), terdapat empat point karakteristik jasa, yaitu :

\section{Tidak Berwujud (Intangibility)}

Jasa bersifat abstrak dan tidak berwujud, jasa tidak dapat dilihat, diraba, didengar, atau dicium sebelum jasa tersebut telah diterima.

2. Bervariasi (Variability) Jasa bersifat nonstandart dan sangat variable. Berbeda dengan kualitas produk fisik yang sudah terstandart, pada kualitas pelayann jasa tergantung 
pada siapa yang menyediakan, kapan, dimana dan bagaimana jasa tersbut diberikan. Karena itulah jasa disebut bervariasi.

3. Tidak dapat dipisahkan (Insenparability)

Umumnya jasa diproduksi dan dikonsumsi pada waktu bersamaan dengan partisipasi konsumen di dalamnya.

4. Tidak dapat disimpan (Pershability) Jasa tidak mungkin disimpan dalam bentuk persediaan. Nilai jasa hanya ada pada saat jasa tersebut diproduksi dan langsung diterima oleh penerimanya. Karakteristik ini berbeda dengan barang berwujud yang dapat diproduksi terlebih dahulu, disimpan, dan dipergunakan lain waktu

\section{Penumpang Dan Barang}

Pengertian penumpang menurut (wikipedia) adalah seseorang yang hanya menumpang, baik itu pesawat, kereta api, bus, maupun jenis transportasi lainnya, tetapi tidak termasuk awak mengoperasikan dan melayani wahana tersebut.

Penumpang dapat diartikan seseorang (individu) dan satu perusahaan (kelompok) yang menggunakan jasa angkutan untuk suatu perjalanan tertentu dengan mengeluarkan sejumlah uang sebagai imbalan bagi pengangkut dengan kata lain dapat didefinisikan orang telah membeli tiket, berarti orang yang melakukan perjalanan dengan menggunakan alat tranportasi yang disediakan oleh pihak pengangkutan atau perusahaan niaga dan terikat kontrak dan persetujuan dengan pengangkut tertera didalam tiket dengan pengangkut selama perjalanan.

Sistem ticketing yang disediakan oleh PT. ALP adalah E-ticketing dengan menggunakan situs keagenan internal yang hanya bisa diakses oleh agen resmi yang sudah melakukan pendaftaran dengan perusahaan, sehingga apabila calon penumpang membeli tiket harus melalui agen yang ditunjuk dan tidak dapat melakukan pencetakan tiket mandiri.

\section{Kapal Ro-Ro}

Menurut pasal 309 ayat (1) KUHD, Kapal adalah semua alat berlayar, apapun nama dan sifatnya. Ro-Ro (Roll on, Roll off) adalah kapal yang didesain untuk bongkar muat barang ke kapal di atas kendaraan roda. Kapal yang termasuk jenis RoRo antara lain kapal Ferry, Kapal pengangkut mobil (Car Ferries), kapal general cargo yang berfungsi sebagai kapal Ro Ro.

\section{E-ticketing}

Menurut Ng-krue dan Swatman (2006), E-Ticketing adalah suatu cara untuk mendokumentasikan proses penjualan dari aktifitas perjalanan pelanggan tanpa harus mengeluarkan dokumen berharga secara fisik ataupun paper ticket. Semua informasi mengenai elektronic ticketing disimpan secara digital dalam sistem komputer perusahaan pelayaran. Sebagai bukti pengeluaran $E$ Ticket, pelanggan akan diberikan Itinerary Receipt yang hanya berlaku sebagai alat untuk masuk kedalam kapal yang masih mengharuskan penumpang membawa tanda bukti perjalanan dan divalidasi dibagian Check in oleh petugas Pelindo di dalam Terminal Penumpang Pelabuhan Tanjung Emas Semarang

Jenis penelitian yang digunakan dalam penelitian ini adalah penelitian kualitatif - deskriptif, Moleong (2004:49) Penelitian pada hakekatnya merupakan suatu upaya untuk menemukan kebenaran atau untuk lebih membenarkan kebenaran. Penelitian jenis apapun titik tolaknya tidak lain bersumber pada masalah. Tanpa masalah penelitian itu tidak dapat dilaksanakan, sehingga ketika akan memulai memikirkan suatu penelitian sudah harus dipikirkan dan dirumuskan secara jelas, sederhana dan tuntas. Hal itu disebabkan oleh seluruh unsur penelitian lainnya berpangkal pada perumusan masalah tersebut. 
Dalam penelitian ini untuk mendapatkan sumber data yang valid, maka peneliti akan melakukan dengan metode wawancara, observasi dan dokumentasi. Dan untuk menganalisis data dalam penelitian ini menggunakan metode analisis oleh Miles dan Huberman dalam Sugiono (2009,h.244) yang meliputi pengumpulan data, reduksi data, penyajian data dan penarikan kesimpulan.

\section{METODE}

Dalam penelitian ini peneliti menggunakan jenis penelitian diskriptif dengan pendekatan kualitatif dan menggunakan metode analisis Miles Huberman.

\section{HASIL DAN PEMBAHSAN}

Dalam upaya peningkatan pelayanan jasa penumpang dan barang, PT. Atosim Lampung Pelayaran Cabang Semarang selalu berusaha secara terus-menerus memperbaiki masalah yang berkaitan dengan kemudahan dalam pembelian ticket, kenyamanan, ketepatan waktu, keselamatan penumpang/barang dan pelayanan. Adapun Strategi yang diterapkan oleh PT. ALP Cabang Semarang dalam peningkatan pelayanan jasa penumpang dan barang transportasi laut dengan menerapkan Lima Elemen Service Quality (ServQual), yang dapat membantu PT. ALP Cabang Semarang dalam meningkatkan pelayanan jasa penumpang dan barang yang sesuai dengan keinginan konsumen.

Terdapat beberapa poin dalam pelaksanaan penerapan Lima Elemen Service Quality (ServQual) diantaranya yang pertama, mengenai Reliability. Seiring dengan kemajuan teknologi, maka PT. ALP dalam kegiatan operasional keagenannya juga telah menggunakan Inaportnet sebagai sarana integritas antar instansi di pelabuhan. Untuk menyeimbangkan kemajuan teknologi tersebut dan juga untuk melayani pemesanan E-ticketing dapat dilakukan melalui internet sehingga waktu lebih efektif dan lebih efisien. Selain teknologi, petugas penyelenggara pelabuhan harus melayani kegiatan agen pelayaran dalam memproses aktivitasnya dibidang pelabuhan agar proses dapat berjalan sesuai dengan jadwal yang ditentukan.

Kedua Assurance, Strategi ini terkait dengan jaminan terhadap kerusakan kendaraan yang membawa muatan. Apabila kerusakan yang terjadi pada kendaraan yang sudah berada di dalam car deck kapal yang akan menuju ke pelabuhan tujuan, dikarenakan lashing yang digunakan oleh petugas sudah tidak layak pakai, dan sudah tua serta berkarat, sehingga kekuatan lashing untuk menahan kendaraan yang membawa muatan kurang kuat, tidak bisa menahan kendaraan yang ada didalam kapal. Pada saat kapal mulai berlayar maka dikhawatirkan kendaraan mengalami tubrukan satu dengan yang lainnya. Lashing seharusnya diganti jika usia lashing sudah melebihi 10 tahun, karena kekuatan ketahanan Seal sudah menurun untuk menahan kendaraan yang memuat barang. Hal tersebut mengakibatkan konsumen mengalami kerugian terhadap kendaraan dan barang yang diangkut. Dalam kasus ini perusahaan mempunyai kebijakan yaitu jika kendaraan benar mengalami kerusakan, maka kerusakan tersebut akan mendapat penggantian baik dari perusahaan atau asuransi, sesuai dengan Prosedur Klaim $E$ ticketing dengan pelaporan kerusakan dari Kantor Cabang dan akan diganti oleh Kantor Pusat melalui Kepala Bagian Komersial setelah mendapatkan ganti rugi dari Jasa Raharja.

Ketiga mengenai Tangible, Elemen ini PT. ALP perlu meningkatkan Sarana Prasarana khususnya dalam sitem Penanganan E-ticketing, karena kurangnya sarana prasarana dalam proses pelayanan $E$ ticketing akan menghambat proses pelayanan dan membutuhkan waktu yang lama mengakibatkan ketidak efisien waktu. Kapal sering mengalami keterlambatan sandar diakibatkan kurangnya sarana prasarana yang ada di pelabuhan, sehingga sering terjadi adanya trouble atau error pada perangkat penunjang yang digunakan 
tersebut, sehingga akan menghambat proses bongkar muat dan akan mempengaruhi terhadap kemunduran jam kapal pada saat akan berangkat. Hal tersebut akan menambah pada biaya operasional kapal di Pelabuhan / Disbursement sehingga kadang akan menimbulkan tambahan waktu (demurage). Adapun Sarana prasarana untuk menunjang kegiatan tersebut adalah :

1. Komputer / Laptop untuk menginput data dan membuat tiket kapal melalui internet.

2. Mesin pencetak tiket/printer yang digunakan untuk mencetak tiket kertas.

3. Alat Check-in Mandiri bagi penumpang.

4. Protofon / Walkie Talkie adalah alat yang digunakan komunikasi dengan pandu untuk kebutuhan agen Clereance in/ out juga digunakan komunikasi untuk mengetahui kapasitas muatan yang akan dimuat keatas kapal dengan petugas lapangan serta petugas lainnya agar lebih terkontrol dan terkendali untuk prosesn bongkar / muat barang .

5. Dermaga, merupakan tempat kapal ditambatkan di pelabuhan dan tempat berlangsungnya bongkar muat.

6. Kendaraan pengangkut, alat transportasi yang digunakan untuk mengangkut barang muatan.

7. Kapal pengangkut barang dan penumpang, merupakan alat transportasi pengangkut penumpang dan barang di laut, alat transportasi yang digunakan untuk penyebrangan antar pulau yang melalui jalur laut, dan yang mempunyai kecepatan, kapasitas ruangan yang sudah ditentukan.

Dalam hal ini untuk mencapai tujuan tersebut PT. ALP Cabang Semarang secara terus -menerus dan berkesinambungan melengkapi fasilitas sarana prasarana agar dapat lebih optimal untuk peningkatan layanan kepada pelanggan.

Keempat tentang Empathy, dalam elemen ini PT. ALP Cabang Semarang bekerjasama dengan Instansi Pelabuhan yakni KSOP, Pelindo III dan yang lainnya sesuai tugas dan fungsi masing-masing instansi (Peraturan Menteri Nomor PM 36 tahun 2012 tentang Organisasi dan Tata kerja, dan UU no. 17 Tahun 2008 tentang Penyelenggaraan Pelabuhan Umum). Untuk pemahaman Konsep antar Pihak yang terlibat dalam sistem penanganan pelayanan E-ticketing yang masih kurang, maka perusahaan terus berusaha untuk memperhatikan keinginan pelanggan dengan memberikan kepercayaan kepada mereka serta bertanggungjawab terhadap kelancaran perjalanan kapal., maka yang dilakukan oleh PT. ALP adalah :

1. Pengecekan kapal sebelum pelayaran, dan memastikan muatan sesuai dengan kapasitas kapal (Cargo DWT)

2. Memastikan terhadap muatan kendaraan yang sudah di lashing dengan baik dan rapat sehingga tidak terjadi benturan pada saat mulai pelayaran.

3. Menggunakan lashing yang sesuai dengan standar dan diperiksa terlebih dahulu sebelum digunakan

4. Petugas lashing untuk kendaraan dipastikan yang ahli dalam bidangnya agar tidak roboh dan terjadi tabrakan saat berada diatas kapal

5. Memastikan terminal Penumpang untuk penumpang yang akan melakukan pelayaran kondisi nyaman.

6. Mengkoordinasikan penyediaan dermaga untuk kapal yang akan melakukan proses bongkar muat.

Kelima adalah Responsiveness (RATER), terkait dengan elemen ini manajemen didalam perusahaan PT. ALP Cabang Semarang juga menerapkan penanganan terhadap keluhan pelanggan yang efektif dengan memberikan peluang untuk mengubah seorang pelanggan yang tidak puas menjadi pelanggan yang puas. Proses penanganan keluhan yang efektif terdiri dari beberapa langkah. Langkah pertama yang dilakukan adalah identifiksi dan penemuan sumber masalah yang menyebabkan pelanggan tidak puas dan mengeluh. Sumber masalah perlu diatasi, ditindaklanjuti dan diupayakan agar 
diwaktu mendatang tidak timbul masalah yang sama. Keterlibatan manajemen puncak dalam penanganan keluhan akan menimbulkan dampak positif, karena pelanggan lebih suka berurusan dengan orang-orang yang memiliki wewenang untuk mengambil keputusan dan tindakan untuk memecahkan masalah mereka. Langkah lain yang lebih penting adalah pengembangan sistem informasi manajemen dengan mendata setiap keluhan yang disampaikan oleh pelanggan dan belajar dari pengalaman agar tidak membuat kesalahan yang sama diwaktu mendatang.

\section{KESIMPULAN}

Berdasarkan data hasil penelitian dan analisis data, maka penulis dapat menarik kesimpulan bahwa :

Strategi peningkatan pelayanan jasa penumpang dan barang pada kapal Ro-Ro adalah memperbaiki pelayanan terkait dengan tujuan perusahaan yaitu sarana prasarana, kenyamanan, keselamatan, jaminan keamanan, dan kepuasan pelanggan /pemakai jasa.

Srategi perusahaan yang pertama terkait dengan Reliability, PT ALP Cabang Semarang melakukan proses pelayanan jasa dengan menggunakan pemesanan $E$ ticketing juga dapat melalui internet sehingga waktu lebih efektif dan lebih efisien. Serta menggunakan Inaportnet sebagai bentuk integritas antar instansi pelabuhan. Kedua Assurance, Strategi ini terkait dengan kebijakan jaminan perusahaan terhadap kerusakan kendaraan yang membawa muatan, sesuai dengan Prosedur Klaim E-ticketing dengan pelaporan kerusakan dari Kantor Cabang dan akan diganti oleh kantor pusat melalui Kepala Bagian Komersial setelah mendapatkan ganti rugi dari Jasa Raharja. Ketiga mengenai Tangible, Elemen ini PT. ALP perlu meningkatkan Sarana Prasarana khususnya dalam sistem Penanganan $E$ ticketing, Dalam hal ini untuk mencapai tujuan tersebut PT. ALP Cabang Semarang secara terus -menerus dan berkesinambungan melengkapi fasilitas sarana prasarana seperti pengadaan alat Check-in Mandiri untuk peningkatan layanan kepada pelanggan. Keempat tentang Empathy Untuk pemahaman Konsep antar Pihak yang terlibat dalam sistem penanganan pelayanan E-ticketing yang masih kurang maka perusahaan terus berusaha untuk memperhatikan keinginan pelanggan dengan memberikan kepercayaan pelanggan serta bertanggungjawab terhadap kelancaran perjalanan kapal dengan pengecekan kapal layak laut ( Seawortyness). Kelima adalah Responsiveness (RATER), terkait dengan elemen ini manajemen didalam perusahaan PT. ALP Cabang Semarang juga menerapkan penanganan terhadap keluhan pelanggan yang efektif dengan memberikan peluang untuk mengubah seorang pelanggan yang tidak puas menjadi pelanggan yang puas. Yang dilakukan dengan langkah-langkah tertentu.

\section{DAFTAR PUSTAKA}

Capt R.P Suyono. 2001 . Shipping Pengangkutan Intermodal Ekspor Impor Melalui Laut. Edisi Revisi .Jakarta PPM

Glueck dan Jauch. 1994. Manajemen Strategis Kebijaksanaan Perusahaan. Jakarta, Erlangga.

Grace Ng-Kruelle, Paul A. Swatman and Oliver Kruelle. 2006. E-Ticketing Strategy and Impelementasi in an Open Access System : The case of Deutsche Bahn.

Moleong,J.Lexy. 2008. Metodologi Penelitian Kualitatif Bandung. PT. Remaja Rosdakarya Offset.

Peraturan Menteri Nomor PM 36 tahun 2012 tentang Organisasi dan Tata kerja.

Sugiyono, 2012. Metode Penelitian Bisnis, Bandung. Alfabeta.

Sugiyono, 2006. Metodelogi Penelitin Kuantitatif, Kualitatif dan $R \& D$. Bandung:Alfabeta. 
The Official MM Academy Coursebook "Service Operation". Esensi.2009

Sumber Ilustrasi: http:// alloinde.com
UU no. 17 Tahun 2008 tentang

Penyelenggaraan Pelabuhan Umum

Undang-undang Nomor 23 Tahun 2014

Tentang pemerintah Daerah. 